\title{
RESPONSE OF SALTBUSH (ATRIPLEX HALIMUS L.) PLANTS TO SALINITY AND TYPE OF GROWING MEDIUM
}

\author{
${\text { Boshra A. El-Sayed }{ }^{*} \text { S.M. Shahin }}^{* *}$ and H.F. El-Tayeb ${ }^{* *}$ \\ * Ornamental Plants and Landscape Gardening Res. Dept., Hort. Res. Inst., ARC, Giza, Egypt. \\ ** Botanical Gardens Res. Dept., Hort. Res. Inst., ARC, Giza, Egypt.
}

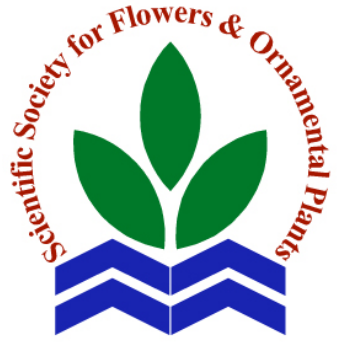

Scientific J. Flowers \& Ornamental Plants, 2(1):135-148 (2015).

Received:

$18 / 12 / 2014$

Revised by:

Prof. Dr. A.Z. Sarhan, Cairo Univ.

Prof. Dr. Eman M. Abou El-Ghait, Banha Univ.
ABSTRACT: A pot experiment was carried out under the full sun at Orman Botanic Garden, Hort. Res. Inst., Giza, Egypt during 2013 and 2014 seasons in order to reveal the effect of different media, namely: pure sand, pure loam and sand + loam mixture at 1:1, 1:2 and 2:1 ratio salinized with a homogenous salt mixture of $\mathrm{NaCl}$ and $\mathrm{CaCl}_{2}(1: 1$, $\mathrm{w} / \mathrm{w})$ at $0.00,0.75,1.5$ and $3.0 \%$ concentrations on growth and chemical composition of the 6-months-old transplants of Mediterranean saltbush (Atriplex halimus L.) cultivated in $40-\mathrm{cm}-$ diameter clay pots filled with a known weight of the abovenamed media.

The results of this experiment have shown that all vegetative and root growth measurements were significantly improved by the law and medium levels of salinity ( 0.75 and $1.5 \%$, respectively), with the mastery of $0.75 \%$ level which gave the highest means various growth traits except of leaf area character that reached the maximum values by $1.5 \%$ level over control and other salinity treatments in the two seasons. However, 3.0\% rate significantly reduced means of the different vegetative and root growth parameters to the least values compared to control in most cases of both seasons. The mixture of sand + loam, especially at $1: 2$ and $2: 1$ ratio recorded the best improvement in vegetative and root growth parameters over all other media in the two seasons. The interaction between the 3 used mixtures salinized with $0.75 \%$ of salt mixture gave the tallest plants, thickest stems and highest No. branches and leaves/plant in both seasons, while the heaviest fresh and dry weights of aerial parts and roots were achieved by $0.75 \%$ salinity level for plants cultivated in either pure sand or pure loam, or in the mixture of both at equal parts (1:1). The content of chlorophyll $\mathrm{a}, \mathrm{b}$ and carotenoids was slightly improved by either soil salinity treatments or media contained loam granulars. On the other side, the content of $\mathrm{Na}, \mathrm{Ca}, \mathrm{Cl}$ and free proline was progressively increased with raising salinity level, but the opposite was the right concerning $\mathrm{K}$ content, which descendingly decreased with increasing salinity rate. The content of $\mathrm{Na}$ and $\mathrm{Cl}$ was not markedly affect by medium type, whereas content of $\mathrm{K}, \mathrm{Ca}$ and free proline was greatly increased in the leaves of plants cultivated in pure loam or pure sand amended with loam at any ratio. The interaction treatments have shown variable effects, as the highest content of $\mathrm{Na}$ and $\mathrm{K}$ was mostly achieved by the low $(0.75 \%)$ and medium $(1.5 \%)$ salinity treatments under loam or sand or sand + loam media, while the highest content of $\mathrm{Ca}, \mathrm{Cl}$ and proline was scored by plants cultured in loam or sand + loam media salinized with the high salinity rate (3.0\%). 


\section{Boshra A. El-Sayed et al.}

It appears from the previous results that Mediterranean saltbush (Atriplex halimus L.) plants can grow well in the loam or sand amended with loam media salinized with $\mathrm{NaCl}+\mathrm{CaCl}_{2}$ salt mixture $(1: 1, w / w)$ at low and medium concentrations.

Key words: Mediterranean saltbush, Atriplex halimus L., soil salinization, type of media, salinity tolerance, vegetative and root growth, chemical composition.

\section{INTRODUCTION}

Atriplex halimus L., Mediterranean saltbush, sea purslane or sea orache (Fam. Chenopodiaceae) is a perennial shrub, up to $2 \mathrm{~m}$ height or less and $3 \mathrm{~m}$ wide, native to Mediterranean basin with an excellent tolerance to drought and salinity (Bailey, 1976). It can easily grown from seeds (sow in the spring and germinate in about 3 weeks) and also from cuttings which can be taken from semi-ripe wood in the summer or mature wood in the winter. It can grow in alkaline or salty soil. Its leaves are a pale green grey (or silver) in colour and have a lovely salty taste when used in salads. They can also be dried and ground down to use as a flavoring. The small seeds are cooked before eating (Huxley et al., 1992). It is characterized by its rapid growth, high biomass production and deep root system, so able to cope with poor structure and xeric characteristics of polluted soils. It is a promising alternative for the removal of heavy metals, including $\mathrm{Pb}$ and $\mathrm{Cd}$ and for soil desalination (Manousaki and Kalogerakis, 2009). In this respect, deSauzaa et al. (2014) recommended to use of the Atriplex for revegetating areas in hospitable to most species used in conventional farming.

For optimal growth Atriplex halimus requires slight salinization of the growth substrate. It tolerates higher salt concentrations, but those above 14 atm retard growth (Blumenthal-Goldschmidt and Poljakoff-Mayber, 1968). In contrast to most plants, $\mathrm{Na}^{+}$absorption by $A$. halimus was not inhibited by high concentrations of $\mathrm{K}^{+}$in the culture medium, while $\mathrm{K}^{+}$absorption was greatly reduced by excess $\mathrm{Na}^{+}$in the growing medium. In $\mathrm{Na}^{+}$and $\mathrm{K}^{+}$were present at equal concentrations, $\mathrm{Na}^{+}$uptake was twice as great as $\mathrm{K}^{+}$. a specific site for $\mathrm{Na}^{+}$absorption which is not inhibited by excess $\mathrm{K}^{+}$in $A$. halimus was postulated (Mozafar et al., 1970). Moreover, Matoh et al. (1986) found that plants of Atriplex gmeline received nutrients supplemented with $50 \mathrm{mM} \mathrm{NaCl}$ gave the maximum dry weight compared to those received the higher or the lower concentrations of $\mathrm{NaCl}$. Addition of $50 \mathrm{mM}$ $\mathrm{KCl}, 25 \mathrm{mM} \mathrm{Na}_{2} \mathrm{SO}_{4}$ or $25 \mathrm{mM} \mathrm{K}_{2} \mathrm{SO}_{4}$ to the base culture also stimulated the growth to the same extent, while higher concentrations of $\mathrm{K}+$ salts, such as $250 \mathrm{mM} \mathrm{KCl}$ or $125 \mathrm{mM}$ $\mathrm{K}_{2} \mathrm{SO}_{4}$ exerted a more deleterious effect on the plant growth than $\mathrm{Na}+$ salts did. At a concentration of $250 \mathrm{mM} \mathrm{NaCl}$ or $\mathrm{KCl}$ addition, the $\mathrm{KCl}$-treated plants showed a higher $\mathrm{Na}^{+}+\mathrm{K}^{+}$concentration than the NaCl-treated plants. The plants exposed to $250 \mathrm{mM} \mathrm{NaCl}$ were able to maintain their internal $\mathrm{Na}^{+}+\mathrm{K}^{+}$concentrations around certain values, while the internal $\mathrm{Na}^{+}+\mathrm{K}^{+}$ concentration in the $250 \mathrm{mM} \mathrm{KCl}$-treated plants increased linearly.

Sadder (2013) mentioned that A. halimus is a xero-halophte shrub adapted to extreme drought and salinity stresses. These characteristics are controlled by special genes which their expression was much higher at $150 \mathrm{mM}$ than $300 \mathrm{mM} \mathrm{NaCl}$ stress level, indicating their specificity for low level salt stress. Photosynthetic activity was slightly decreased with both extended stress exposure and increased salt concentration, while total chlorophyll and proline increased under saline stress. Similar observations were also recorded on other trees and suburbs, such as those of Al-Qubaie et al. (2003) on Ficus benghalensis, Tamarix articulata, Jasminum azoricum, Concarpus erectus and Ziziphus spina-christi, Mahmoud 
(2005) on Cocos romanzoffiana, Livistona chinensis, Sabal palmetto and Washingtonia filifera. Shahin et al. (2008) on Ficus macrocarpa var. Hawaii and Euonymus japonica, Abdel-Fattah et al. (2012) on Ficus retosa and Shahin et al. (2013) on F. benjamina cv. Smantha and Schefflera arboricola cv. Gold Capella.

This work was set out in order to study the effect of salinized different media on growth performance and chemical composition of saltbush plants.

\section{MATERIALS AND METHODS}

This investigation was performed under the full sun at Orman Botanic Garden, Hort. Res. Inst., Giza, Egypt during the two successive seasons of 2013 and 2014 to explore the response of saltbush plants grown in different media salinized with the various levels of $\mathrm{NaCl}+\mathrm{CaCl}_{2}$ salt mixture.

Thus, six months-old, uniform transplants of saltbush (Atriplex halimus L.) at a length of about $25 \mathrm{~cm}$ were planted on April, $1^{\text {st }}$ for each season in $40-\mathrm{cm}$-diameter clay pots (one transplant/pot) filled with one type of the following media: pure sand, pure loam, as well as sand + loam mixture at the following ratios 1:1, 1:2 and 2:1. The physical and chemical properties of the sand and loam used in the two seasons are shown in Table (1).

The pots were filled with each one of the above-named media 1 inch before the rim. Then, weight of each medium occupied that space was calculated individually. Thereafter, the used media were salinized with an equal mixture of $\mathrm{Nacl}$ and $\mathrm{CaCl}_{2}$ pure salts $(1: 1$, by weight) at the following concentrations: 0.00 , $0.75,1.5$ and $3.0 \%$. Hereafter, Table (2), showing the amount of salt mixture which was added to each pot according to type of medium and its weight.

The treatments of media and salinization were combined factorially to create 20 interaction treatments. Immediately after planting the transplants were irrigated with $400 \mathrm{ml}$ of fresh water/pot, twice a week till the end of experiment on October, $1^{\text {st }}$.

Table 1. The physical and chemical properties of the sand and loam used in the two seasons.

\begin{tabular}{|c|c|c|c|c|c|c|c|c|c|c|c|c|c|c|c|}
\hline \multirow{2}{*}{$\begin{array}{c}\text { Soil } \\
\text { texture }\end{array}$} & \multirow[b]{2}{*}{ Seasons } & \multicolumn{4}{|c|}{ Particle size distribution (\%) } & \multirow[b]{2}{*}{ S.P. } & \multirow{2}{*}{$\begin{array}{c}\text { E.C. } \\
(\mathrm{dS} / \mathrm{m})\end{array}$} & \multirow[b]{2}{*}{ pH } & \multicolumn{4}{|c|}{ Cations (meq/l) } & \multicolumn{3}{|c|}{ Anions (meq/l) } \\
\hline & & $\begin{array}{c}\text { Coarse } \\
\text { sand }\end{array}$ & $\begin{array}{l}\text { Fine } \\
\text { sand }\end{array}$ & Silt & Clay & & & & + & 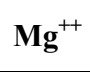 & $a^{+}$ & $\mathbf{K}^{+}$ & & $I^{-}$ & $\mathrm{SO}_{4}^{--}$ \\
\hline \multirow{2}{*}{ Sanc } & & & 205 & & 8.52 & 23.01 & & 7.90 & 7.50 & 1.63 & 33.60 & 0.50 & 3.20 & 22.00 & 18.03 \\
\hline & 2014 & 4.76 & 6.29 & 1.50 & 7.45 & 21.87 & 3.71 & 7.80 & 19.42 & 8.33 & 7.20 & 0.75 & 1.60 & 7.80 & 26.30 \\
\hline \multirow{2}{*}{ Loam } & 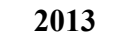 & & 46.17 & 19.53 & 24.12 & 35.00 & 3.48 & 8.27 & 17.50 & 9.42 & 20.00 & 0.79 & 3.80 & 10.00 & 33.91 \\
\hline & 14 & .30 & 6.54 & 18.88 & 24.28 & 33.07 & 3.36 & 7.96 & 18.00 & 8.95 & 20.50 & 0.85 & 3.65 & 10.20 & 34.45 \\
\hline
\end{tabular}

Table 2. The salts mixture weight (g) added to each pot according to medium type and its weight filling it 1 inch before the rim in both seasons.

\begin{tabular}{lcccccccccc}
\hline & Medium & \multicolumn{2}{c}{ Sand } & \multicolumn{2}{c}{ Loam } & \multicolumn{2}{c}{$\begin{array}{c}\text { Sand + loam } \\
(\mathbf{1 : 1 )}\end{array}$} & \multicolumn{2}{c}{$\begin{array}{c}\text { Sand + loam } \\
(\mathbf{1 : 2})\end{array}$} & \multicolumn{2}{c}{$\begin{array}{c}\text { Sand + loam } \\
(\mathbf{2 : 1})\end{array}$} \\
\cline { 2 - 11 } Soil salinity & $\mathbf{2 0 1 3}$ & $\mathbf{2 0 1 4}$ & $\mathbf{2 0 1 3}$ & $\mathbf{2 0 1 4}$ & $\mathbf{2 0 1 3}$ & $\mathbf{2 0 1 4}$ & $\mathbf{2 0 1 3}$ & $\mathbf{2 0 1 4}$ & $\mathbf{2 0 1 3}$ & $\mathbf{2 0 1 4}$ \\
\hline Medium weight (kg/pot) & 9.73 & 9.81 & 7.47 & 7.53 & 8.00 & 8.10 & 8.80 & 8.71 & 9.00 & 8.92 \\
Control & 0.00 & 0.00 & 0.00 & 0.00 & 0.00 & 0.00 & 0.00 & 0.00 & 0.00 & 0.00 \\
$\mathbf{0 . 7 5} \%$ salinity & 73.00 & 73.58 & 56.00 & 56.48 & 60.00 & 60.75 & 66.00 & 65.33 & 67.50 & 66.90 \\
$\mathbf{1 . 5 0} \%$ salinity & 146.00 & 147.16 & 112.00 & 112.96 & 120.00 & 121.50 & 132.00 & 130.66 & 135.00 & 133.80 \\
$\mathbf{3 . 0 0} \%$ salinity & 219.00 & 220.74 & 168.00 & 169.44 & 180.00 & 182.25 & 198.00 & 195.99 & 202.50 & 200.70 \\
\hline
\end{tabular}


However, the other agricultural practices required for such plantation were done well whenever needed. The pots were arranged in the two seasons in a factorial complete randomized design replicated thrice with 5 transplants per replicate (Mead et al., 1993). At the end of each season, data were recorded as follows plant height $(\mathrm{cm})$, stem diameter at the base $(\mathrm{cm})$ number of branches and leaves/plant, leaf area $\left(\mathrm{cm}^{2}\right)$ as well as fresh and dry weights of aerial parts and roots $(\mathrm{g})$.

In fresh leaf samples taken from the middle parts of plants, the photosynthetic pigments content (chlorophyll a, b and carotenoids, $\mathrm{mg} / \mathrm{g}$ f.w.) was determined according to the method described by Saric et al. (1967), while in dry leaf samples, the percentages of sodium and potassium as well as chloride in $\mathrm{mg} / \mathrm{g}$ d.w. (Jackson, 1973) and calcium (Dewis and Freitas, 1970) were measured. Furthermore, content of the free amino acid proline as $\mu$ moles/g d.w. was assessed using the method explained by Bates et al. (1973).

Data were then tabulated and the morphological ones were undergone to analysis of variance using the program of SAS Institute Program (1994), followed Duncan's Multiple Range Test (Duncan, 1955), to detect the significancy among the means of various treatments.

\section{RESULTS AND DISCUSSION}

\section{Effect of salinity, media and their interactions on:}

\section{1-Vegetative and root growth parameters:}

It is obvious from data illustrated in Tables (3, 4, 5, 6 and 7) that all vegetative and root growth parameters, expressed as plant height $(\mathrm{cm})$, stem diameter $(\mathrm{cm})$, number of branches and leaves/plant, leaf area $\left(\mathrm{cm}^{2}\right)$, as well as fresh and dry weights of aerial parts and roots (g) were significantly improved as a result of planting in media salinized with the medium levels of salt mixture $(0.75$ and $1.5 \%)$ with the superiority of $0.75 \%$ level that gave the highest means of all above-named traits except of leaf area criterion which reached the maximum by $1.5 \%$ level over control and other salinity treatments in the two seasons. On the other hand, $3.0 \%$ salinity level significantly reduced all vegetative and root growth characters compared to control in most cases of the two seasons.

These results may demonstrated that growth of saltbush plants was strongly stimulated by low level of saline media containing equal parts of $\mathrm{NaCl}$ and $\mathrm{KCl}$ or $\mathrm{CaCl}_{2}$, as indicated before by Mozafar et al. (1970) and Blumenthal-Goldschmidt and Poljakoff-Mayber (1968). In this regard, Manousaki and Kalogerakis (2009) noticed that salt toxicity symptoms were observed only in A. halimus plants treated with 3\% $\mathrm{NaCl}$ solution. The reduction of growth due to high salinity may be attributed to a decrease in all volume at a constant cell number caused by salinity (deSouzaa, 2014). Sadder (2013) mentioned that mechanism of salt may result in cell division inhibition and hence reduces the rate of plant growth. Moreover, Gale and Poljakoff-Mayber (1970) stated that there are at least 3 different effects of salinity on A. halimus plants: an increase of leaf area and succulence induced by relatively low concentration of salt in the growth medium, an increase of stomatal resistance to water vapour loss, this tended to reduce transpiration per unit of leaf area and changes in mesophyll resistance to $\mathrm{CO}_{2}$ uptake which reduced by relatively low concentration of $\mathrm{NaCl}$. In addition, salinity may have caused a hormonal imbalance which increased sprouting of lateral buds.

Blumenthal-Goldschmidt and PoljakoffMayber (1968) affirmed that some changes occur in the submicroscopic structure of leaf cells of $A$. halimus at 9-14 atm salt concentration, including : swelling of chloroplasts and mitochondria, appearance of numerous large lipid droplets, swelling of the nuclear membranes, extensive vacuolization and distortion of the transplant with formation of numerous myelin bodies. Besides, Smaoui et al. (2011) revealed that A. halimus has secreting glandular trichomes which are recognized as an efficient structure 
Scientific J. Flowers \& Ornamental Plants, 2(1):135-148 (2015)

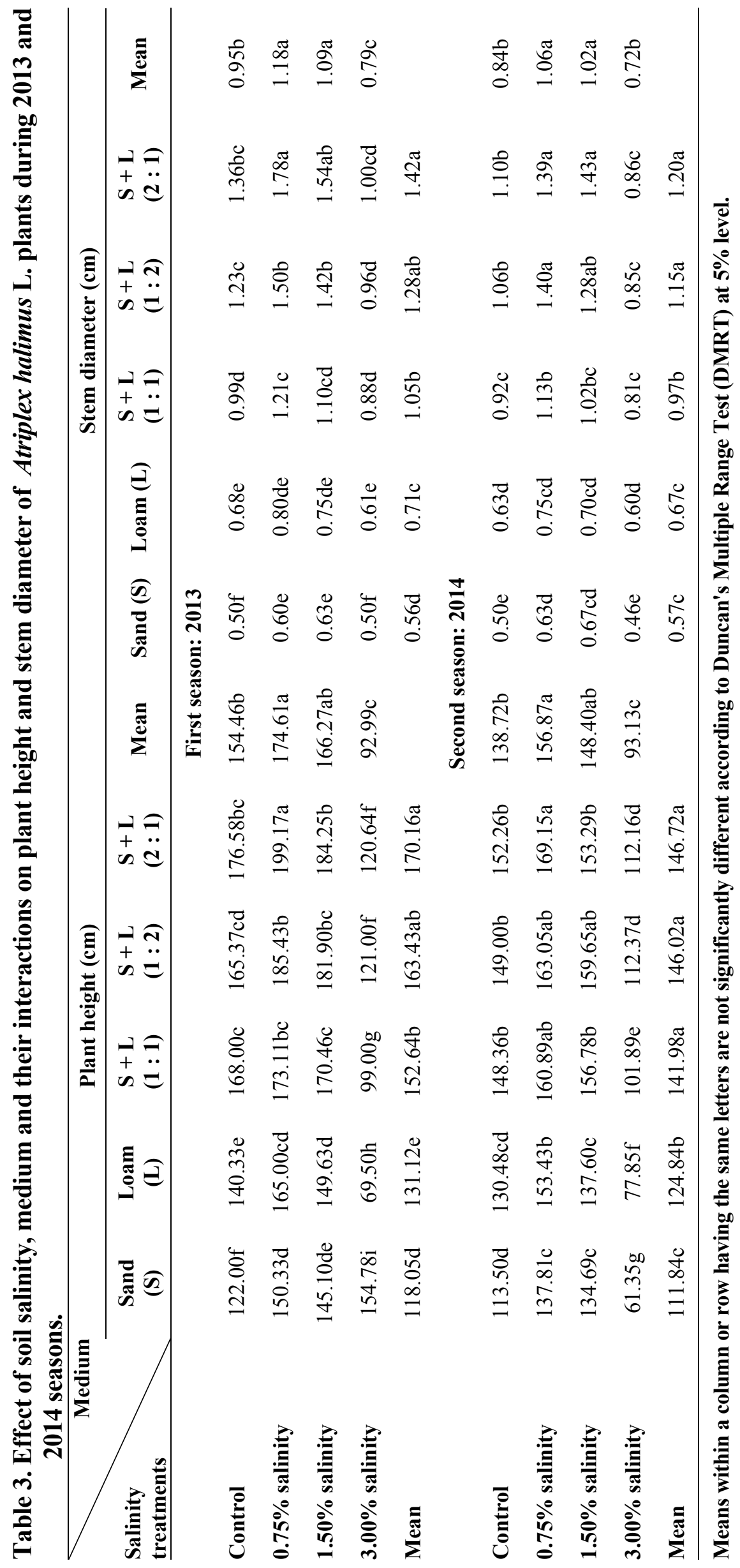


Boshra A. El-Sayed et al.

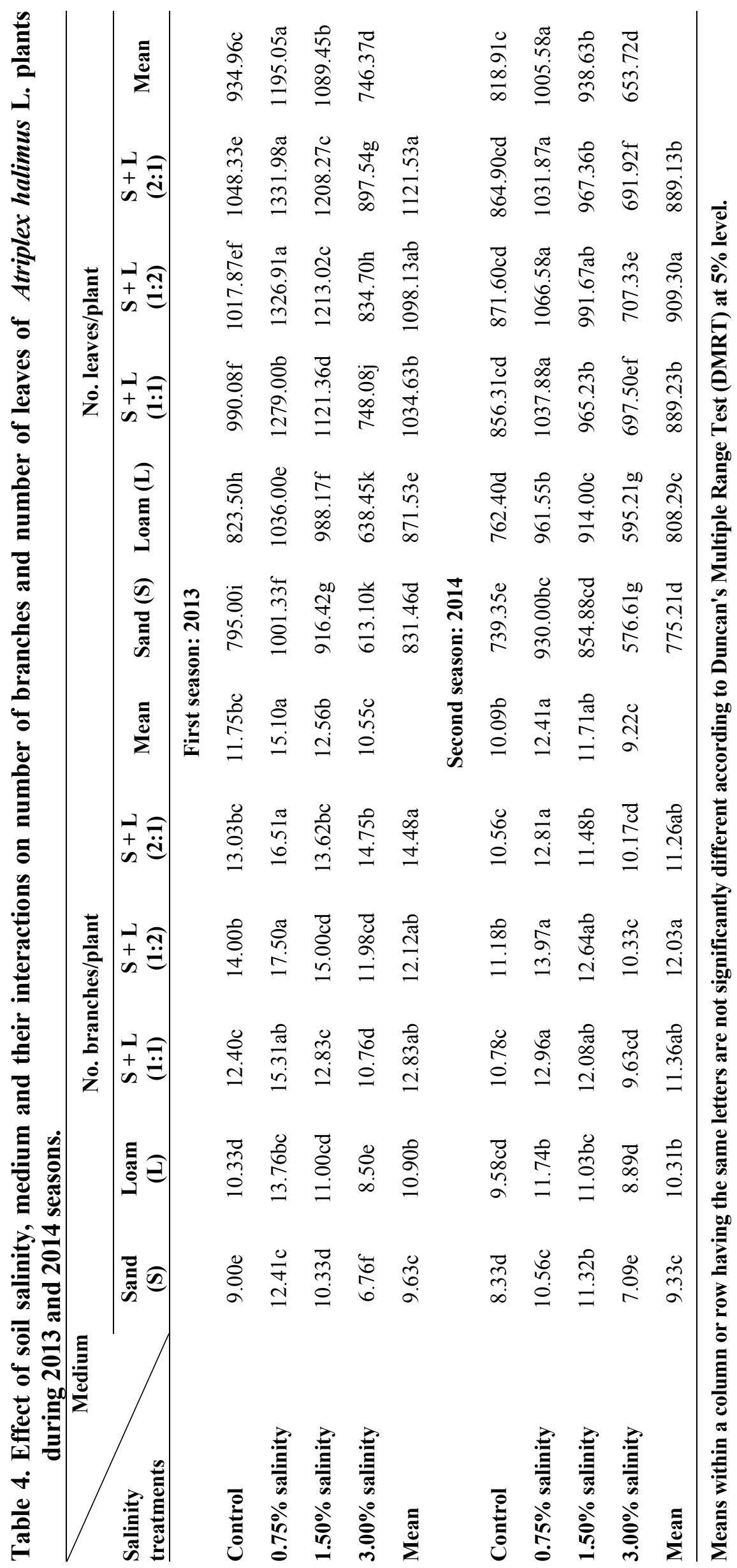




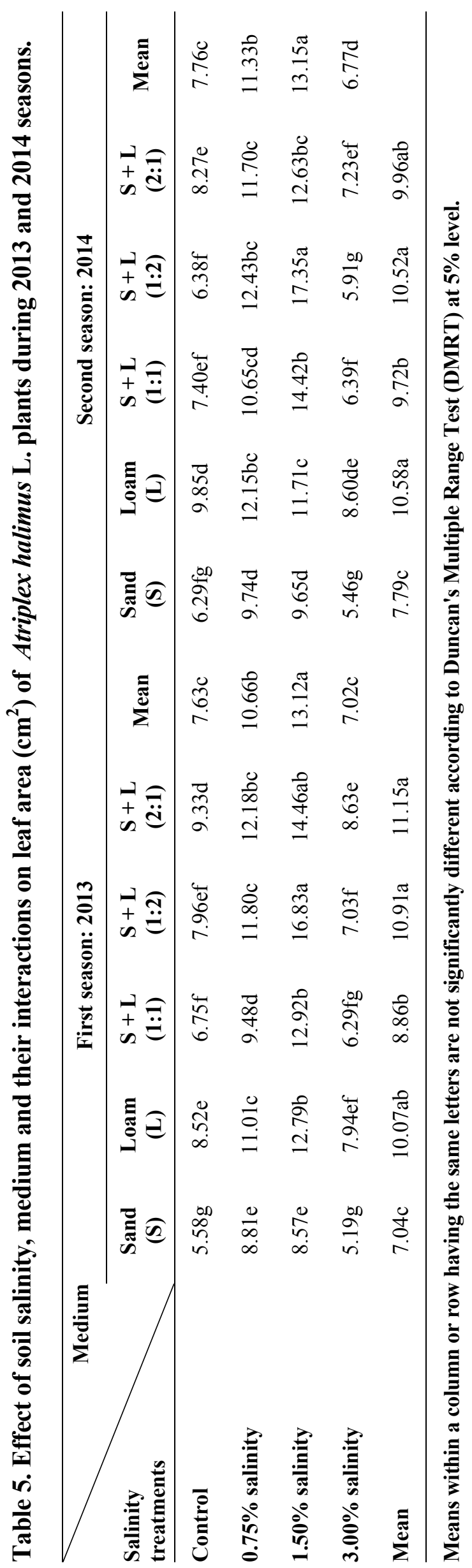


Boshra A. El-Sayed et al.

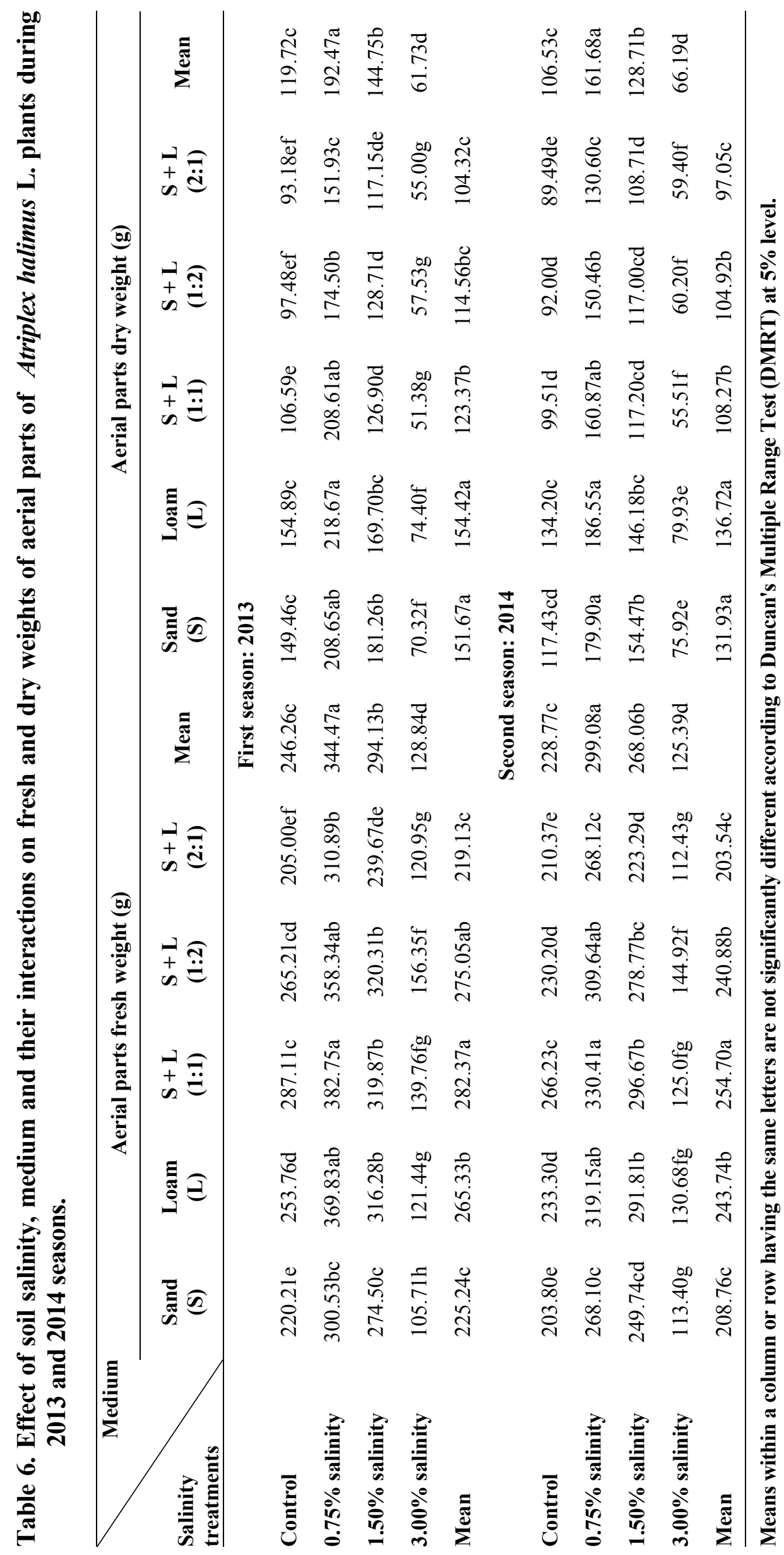




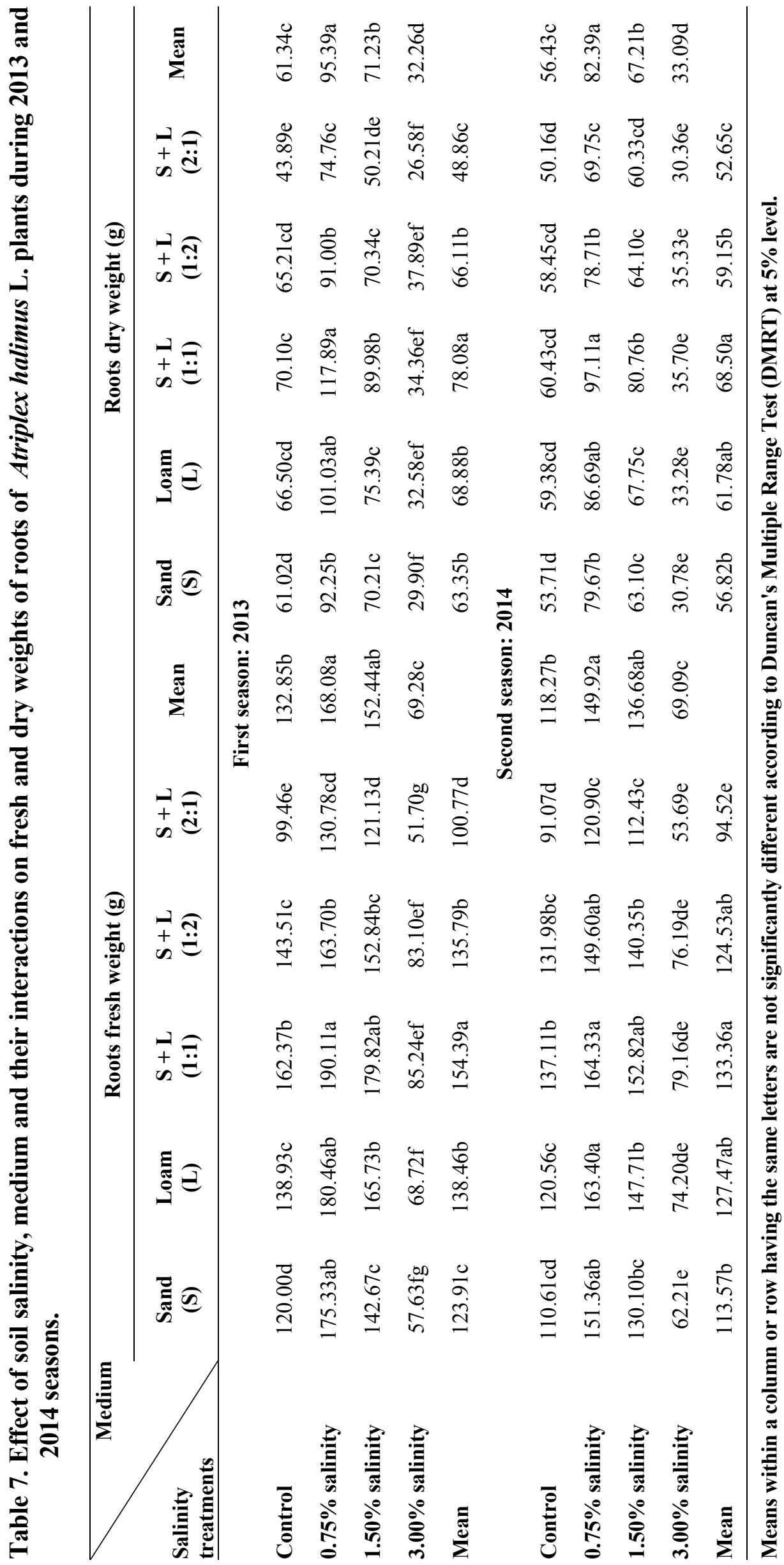


that alleviates salt effects on such plant. They are found on buds, young green stems and occupy both the leaf surfaces and give them a whitish colour. In this concern Mozafar and Goodin (1970) found that the concentration of salt in the vesiculated hairs of A. halimus was remarkably higher than that of the leaf sap and xylem exudate. This observation indicates that in A. halimus the vesiculated hairs play a significant role in removing salts from the remainder of the leaf and preventing the accumulation of toxic salts in the parenchyma and vescular tissues. Thus, a nearly constant salt content is maintained in leaf cells other than the hairs.

As for the effect of media, data indicated that sand + loam mixtures registered the best results compared to the pure sand or loam in most cases of the two seasons, with the prevalence of $1: 2$ and $2: 1(\mathrm{~S}+\mathrm{L})$ ratio which often recorded the highest averages in both seasons. This may be due to that saltbush plants grow well in any light, welldrained, but not too febrile soil (Rofe, 2012). Cultivating in either pure sand or pure loam scored only the heaviest aerial parts dry weights over the 3 used soil mixtures in the two seasons, whereas cultivating in the equal mixture of sand + loam $(1: 1)$ gave the heaviest fresh and dry weights of roots relative to the other media used in both seasons.

The interaction treatments were also exhibited a marked effect on growth of saltbush plants where planting in the 3 mixtures salinized with $0.75 \%$ of salt mixture gave the best plant height, stem diameter and No. of branches and leaves/plant in the two seasons, while the best leaf are was attained by the interaction between sand + loam mixture (1:2) and salinization with $1.5 \%$ of salt mixture. However, the heaviest fresh and dry weights of aerial parts and roots in both seasons were achieved by $0.75 \%$ salinity level plus cultivating in pure sand, pure loam or in the mixture of both at equal parts $(1: 1)$. This may be ascribed to lumping the beneficial effect of low and medium salinity on saltbush growth (Mozafar et al., 1970 and Matoh et al., 1986) and the presence of loam granulars which improve soil texture, structure and fertility, besides increasing capacity of both water holding and cation exchangeable that play a vital role in keeping nutrients from loss with drainage water as induce in the pure sand soil.

These findings are in harmony with those postulated by Mozafar et al. (1970) and Sadder (2013) on Atriplex halimus, Matoh et al. (1986) on Atriplex gmelini, Abdel-Fattah et al. (2012) on Ficus retosa and Shahin et al. (2013) on Ficus benjamina cv. Samantha and Schefflera arboricola cv. Gold Capella.

\section{2- Chemical composition:}

Data in Table (8) clear that, chlorophyll $\mathrm{a}, \mathrm{b}$ and carotenoids content (mg/g f.w.) slightly improved by either soil salinity treatments or media contained loam granulars. However the highest content of the different pigments was attained by the medium level of salinization (1.5\%) under the various used media followed by the low salinity level $(0.75 \%)$ which occupied the second rank in this concern. This result is supported by that of Manousaki and Kalogerakis (2009) whom found that the amount of photosynthetic pigments were increased in the leaves of Atriplex halimus plants irrigated with $\mathrm{NaCl}$ solution up to $3 \%$ concentration. Furthermore, Sadder (2013) reported that photosynthetic activity in the leaves of A. halimus was slightly decreased with both extended stress exposure (from $30 \mathrm{~h}$ to $70 \mathrm{~h}$ ) and increased salt concentration (from 150 to 300 and $600 \mathrm{mM} \mathrm{NaCl}$ ), while total chlorophyll and proline increased under saline stress.

On the other side, the percentages of $\mathrm{Na}$ and $\mathrm{Ca}$, as well as $\mathrm{Cl}(\mathrm{mg} / \mathrm{g} \mathrm{d.w.})$ and free proline ( $\mu$ moles/g d.w.) contents were progressively increased with increasing salinity, but the opposite was the right regarding $\mathrm{K} \%$, which descendingly decreased with increasing salinity rate (Tables, 9 and 10). That is because high salinity usually 


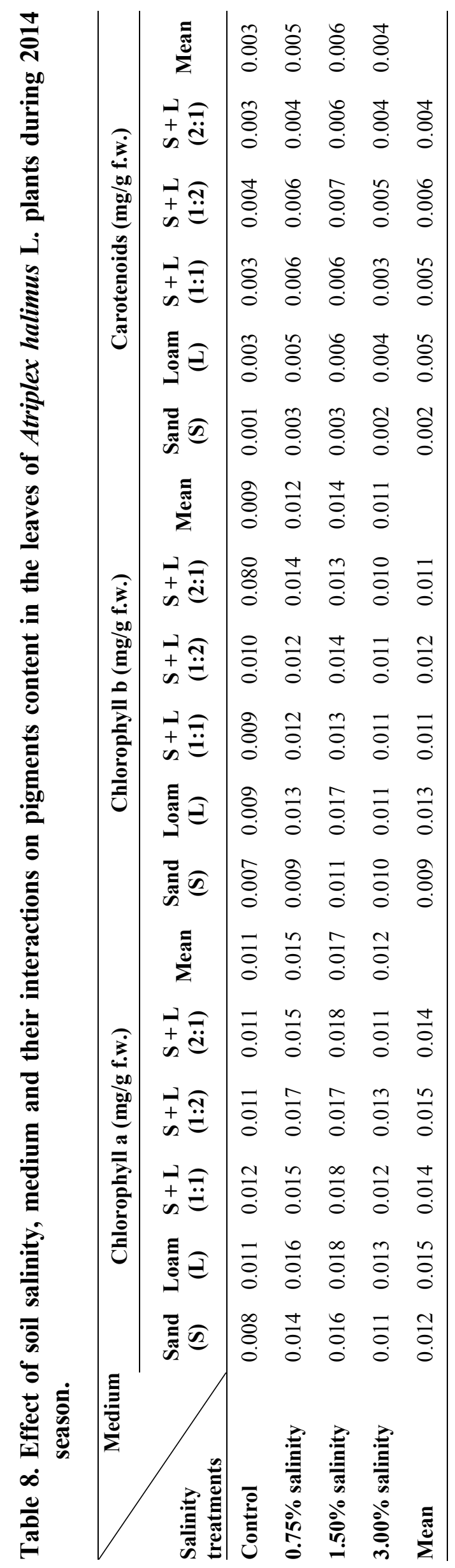

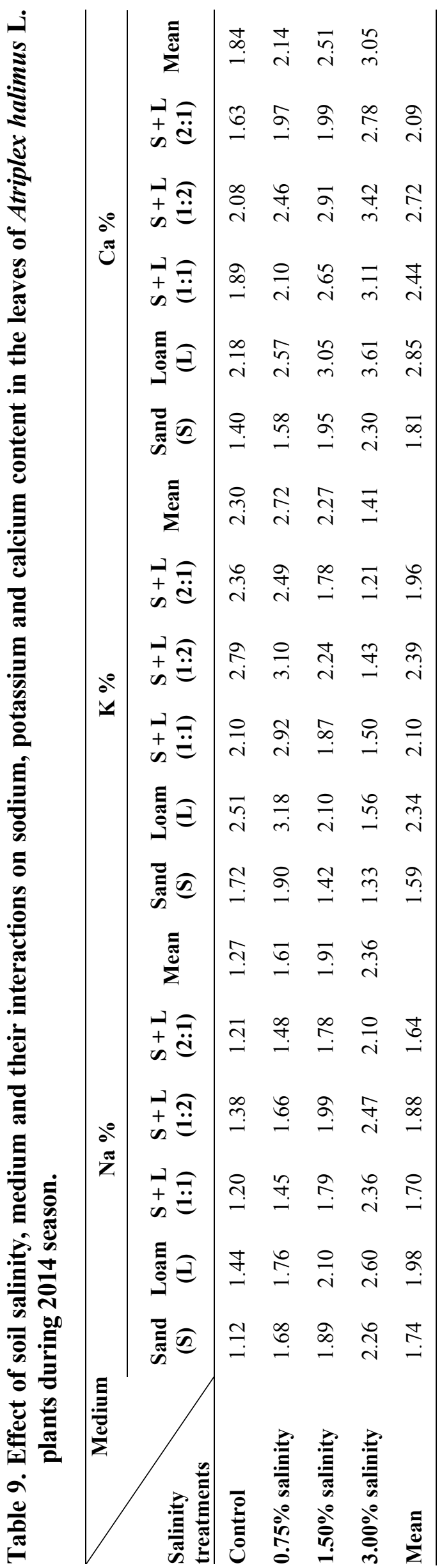


Table 10. Effect of soil salinity, medium and their interactions on chloride and free proline content in the leaves of Atriplex halimus L. plants during 2014 season.

\begin{tabular}{|c|c|c|c|c|c|c|c|c|c|c|c|c|}
\hline \multirow[b]{2}{*}{$\begin{array}{l}\text { Salinity } \\
\text { treatments }\end{array}$} & \multicolumn{6}{|c|}{ Cl (mg/g d.w.) } & \multicolumn{6}{|c|}{ Free proline ( $\mu$ moles/g d.w.) } \\
\hline & $\begin{array}{l}\text { Sand } \\
\text { (S) }\end{array}$ & $\begin{array}{c}\text { Loam } \\
\text { (L) }\end{array}$ & $\begin{array}{l}S+L \\
(1: 1)\end{array}$ & $\begin{array}{l}S+L \\
(1: 2)\end{array}$ & $\begin{array}{l}S+L \\
(2: 1)\end{array}$ & Mean & $\begin{array}{l}\text { Sand } \\
\text { (S) }\end{array}$ & $\begin{array}{l}\text { Loam } \\
\text { (L) }\end{array}$ & $\begin{array}{l}S+L \\
(1: 1)\end{array}$ & $\begin{array}{l}S+L \\
(1: 2)\end{array}$ & $\begin{array}{l}S+L \\
(2: 1)\end{array}$ & Mean \\
\hline Control & 1.85 & 1.99 & 1.92 & 2.07 & 1.56 & 1.88 & 1.10 & 2.70 & 2.11 & 2.34 & 1.87 & 2.03 \\
\hline $0.75 \%$ salinity & 2.27 & 2.48 & 2.34 & 2.58 & 1.94 & 2.32 & 2.31 & 5.78 & 4.40 & 5.09 & 3.93 & 4.30 \\
\hline $1.50 \%$ salinity & 3.98 & 4.41 & 3.50 & 3.79 & 3.28 & 3.79 & 4.85 & 10.91 & 9.29 & 11.32 & 8.25 & 8.93 \\
\hline $3.00 \%$ salinity & 6.10 & 5.38 & 5.21 & 5.67 & 4.68 & 5.41 & 10.27 & 18.47 & 13.45 & 18.69 & 15.32 & 15.24 \\
\hline Mean & 3.55 & 3.57 & 3.24 & 3.53 & 2.87 & & 4.63 & 9.47 & 7.31 & 9.36 & 7.34 & \\
\hline
\end{tabular}

leads to increase the uptaking of some highly hydrophilic ions (e.g. $\mathrm{Na}$ and borate) as indicated by Handreck and Black (2002). It was also suggested that accumulation of some amino acids and amides in the leaves of salinity stressed-plants may be due to denovo synthesis and not the result of protein degradation (Sadder, 2013). The content of $\mathrm{Na}$ and $\mathrm{Cl}$ was not greatly affect by medium type, whereas content of $\mathrm{K}, \mathrm{Ca}$ and free proline was markedly increased in the leaves of plants cultivated in pure loam or pure sand amended with loam at any percent. This may be attributed to the role of loam granulars in improving texture, structure and fertility of soil mixture, beside enhancing cation exchange capacity. The interaction between salinity and medium shown variable responses, as the highest content of $\mathrm{Na}$ and $\mathrm{K}$ was mostly achieved by either low $(0.75 \%)$ or medium $(1.5 \%)$ salinity level under loam or sand + loam media, while the highest content of $\mathrm{Ca}, \mathrm{Cl}$ and proline was noticed in plants cultured in loam and sand + loam media salinized with the high salinity rate $(3.0 \%)$.

Analogous observations were also obtained by Mozafar et al. (1970) on Atriplex halimus, Matoh et al. (1986) on Atriplex gmelini, Al-Qubaie et al. (2003) on Ficus benghalensis, Tamarix articulata, Jasminum azoricum, Conocarpus erectus and Ziziphus spina-christi and Shahin et al. (2008) on Ficus macrocarpa var. Hawaii and Euonymus joponicus cv. Aureus.

It appears from the previous gains that Mediterranean saltbush (Atriplex halimus L.) plants can grow well in the loam or sand amended with loam salinized with $\mathrm{NaCl}+$ $\mathrm{CaCl}_{2}(1: 1 \mathrm{w} / \mathrm{w})$ at medium and low levels.

\section{REFERENCES}

Abdel-Fattah, Gehan H.; Shahin, S.M. and Abdel-Moniem, Azza M. (2012). Improving tolerance of Ficus retosa L. plant to saline water stress by VAM (Glomus sp.). J. Biol. Chem. \& Environ. Sci., 7(1):1-16.

Al-Qubaie, A.I.; Shahin, S.M. and AlToukhy, A.A. (2003). Response of some ornamental trees and shrubs to irrigation intervals. Egypt J. Appl. Sci., 18(8 B):602-617.

Bailey, L.H. (1976). Hortus Third, Macmillan Publishing Co., Inc., 866 Third Avenue, New York, N.Y. 10022.1290 pp.

Bates, L.S.; Waldern, R.P. and Tear, I.D. (1973). Rapid determination of free proline under water stress studies. Plant and Soil, 39:205-207. 
Blumenthal-Goldschmidt, S. and PoljakoffMayber, A. (1968). Effect of substrate salinity on growth and on submicroscopic structure of leaf cells of Atriplex halimus L. Australian J. Botany, 16(3):439-478.

deSauzaa, E.R.; dosSantos, Maria B.; deMeloa, D.V. and Montenegroa, A.A. (2014). Management of Atriplex nummularia Lindl in a salt affected soil in semi-arid region of Brazil. Inter. J. of Phytoremediation, 16(1):73-85.

Dewis, J. and Freitas, F. (1970). Physical and Chemical Methods of Soil and Water Analysis. FAO, Rome, Italy; 70-71.

Duncan, D.B. (1955). Multiple range and multiple F-tests. J. Biometrics, 11:1-24.

Gale, J. and Poljakoff-Mayber, A. (1970). Interrelation between growth and photosynthesis of saltbush (Atriplex halimus L.) grown in saline media. Australian J. Biol. Sci., 23(4):37-946.

Handreck, K. and Black, N. (2002). Growing Media for Ornamental Plants and Turf. $3^{\text {rd }}$ Ed., Univ. of New South Walls Press Ltd., Sydney, Australia, 542 pp.

Huxley, A.; Griffiths, M. and Levy, M. (1992). The New Royal Horticultural Society Dictionary of Gardening. The Stockton Press, 257 Park Avenue South, New York, N. Y. 10010, USA, Vol. 2, $747 \mathrm{pp}$.

Jackson, M.H. (1973). Soil Chemical Analysis. Prentice-Hall of India Private Limited M-97, New Delhi, India, 498 pp.

Mahmoud, A.M.A. (2005). Studies on Soil Salinity Tolerance of Some Ornamental Palm Genera. Ph.D. Thesis, Fac. Agric., Kafr El-Sheikh, Tanta Univ.

Manousaki, E. and Kalogerakis, N. (2009). Phytoextraction of $\mathrm{Pb}$ and $\mathrm{Cd}$ by the Mediterranean saltbush (Atriplex halimus L.): metal uptake in relation to salinity. Environ. Sci. and Pollution Res., 16(7):844-854.

Matoh, T. Watanabe, J. and Takahashi, E. (1986). Effect of sodium and potassium salts on the growth of a halophyte Atriplex gmelini. Soil Sci. and Plant Nutrition, 32(3):451-459.

Mead, R.; Curnow, R.N. and Harted, A.M. (1993). Statistical Methods in Agriculture and Experimental Biology. $2^{\text {nd }}$ Ed., Chapman \& Hall Ltd., London, 335 pp.

Mozafar, A. and Goodin, J.R. (1970). Vesiculated hairs: A mechanism for salt tolerance in Atriplex halimus L. Plant Physiol., 45(1):62-65.

Mozafar, A.; Goodin, J.R. and Oertli, J.J. (1970). Sodium and potassium interactions increasing the salt tolerance of Atriplex halimus L.: II. $\mathrm{Na}^{+}$and $\mathrm{K}^{+}$ uptake characteristics. Agronomy J., 62(4):481-484.

Rofe, A. (2012). Mediterranean saltbush (Atriplex halimus L.). http:// rawedibleplants.blogspot.com/2012/01/m editeranean - saltbush - atriplexhalimus. html.

Sadder, M.T. (2013). Gene expression and physiological analysis of Atriplex halimus L. under salt stress. Australian J. of Crop. Sci., 7(1):112-118.

Saric, M.; Kastrori, R.; Curic, R.; Cupina T. and Geric, I. (1967). Chlorophyll Determination. Univ U Noven Sadu Parktikum is Fiziologize Biljaka, Beogard, Haucna, Anjige, 215 pp.

SAS Institute Program (1994). SAS/STAT User's Guide, Statistics. Vers. 6.04, $4^{\text {th }}$ Ed., SAS. Institute Inc. Cary, N.C., USA.

Shahin, S.M.; El-Fouly, Amal S. and AbdelSattar, M.M. (2013). Response of $F$. benjamina L. cv. Samantha and Schefflera arboricola Endl cv. Gold Copella plants cultivated in two different growing media to salinity of irrigation water. J. Biol. Chem. \& Environ. Sci., 8(2):201-218.

Shahin, S.M.; Eliwa, Naglaa Y.; Mahmoud, A.M.A. and El-Feky, A.H. (2008). How far diluted sea water can be used for irrigation of some pot plants? $9^{\text {th }}$ Inter. 
Boshra A. El-Sayed et al.

Conf. on Dry Land Development, 7-10 Nov., Organized by IDDC, Alex., Egypt: potential ion transport pathways in 363-372.

vesicular trichome cells of Atriplex halimus L. Protoplasma, 248(2):363-372.

Smaoui, A.; Barhoumi, Z.; Rabhi, M. and

Abdelly, C. (2011). Lozalization of

\section{استجابة نباتات شجيرة الملح (القطف) لملوحة ونوع بيئة النمو}

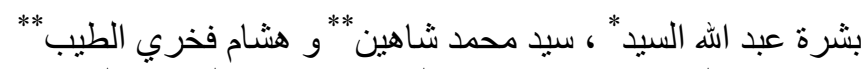

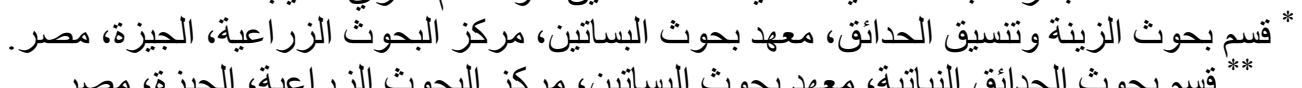

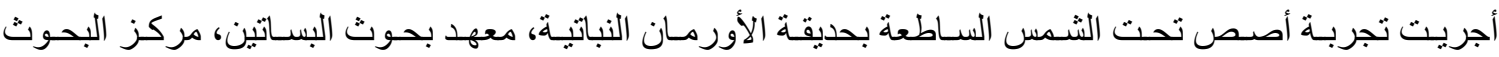

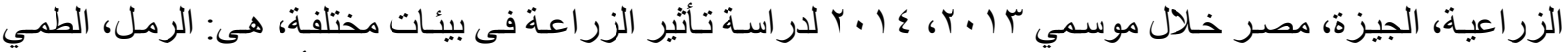

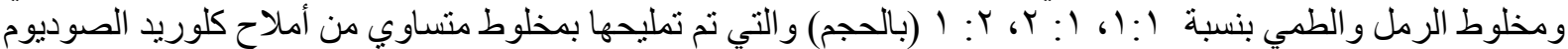

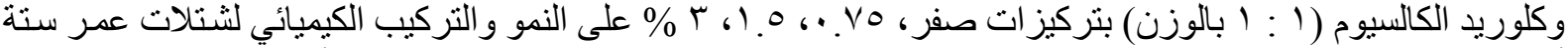

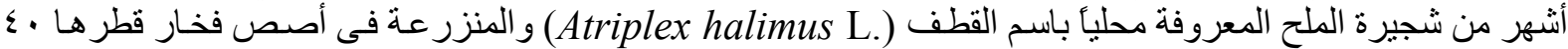

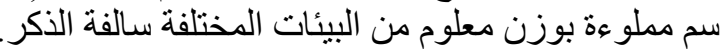

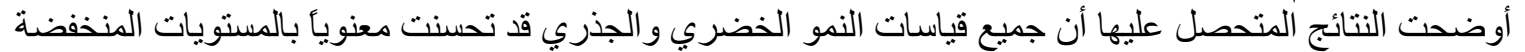

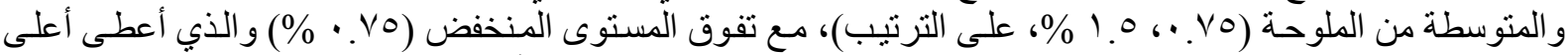

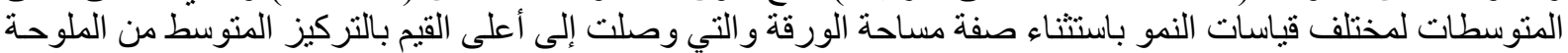

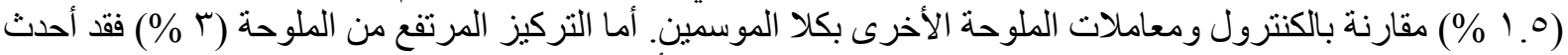

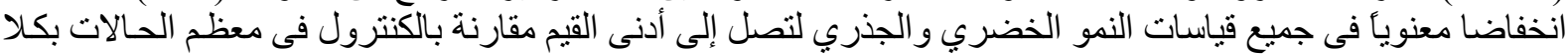

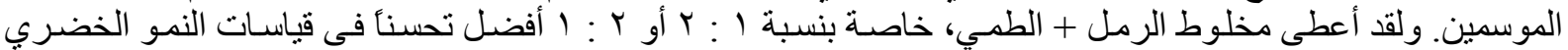

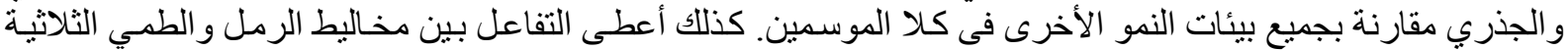

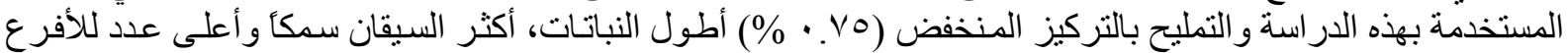

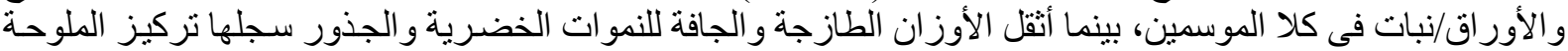

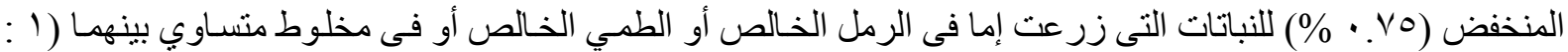

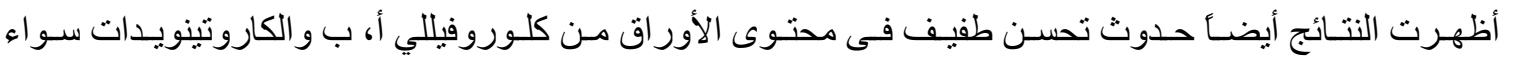

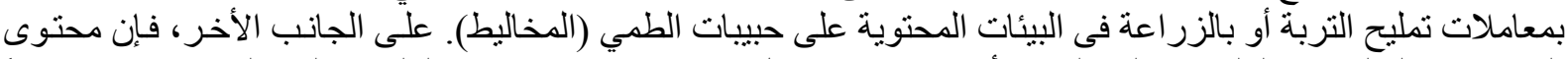

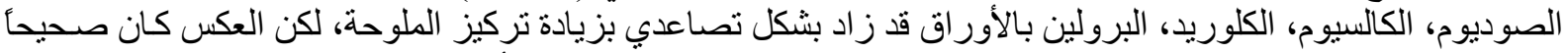

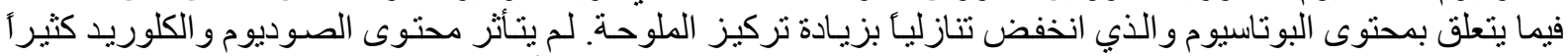

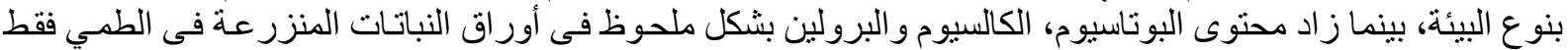

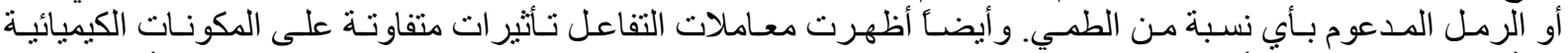

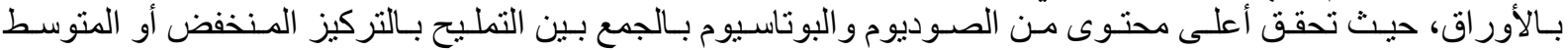

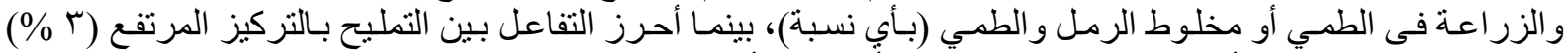

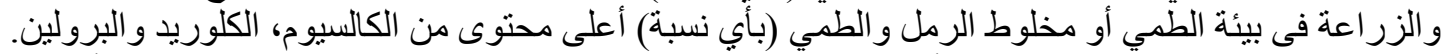

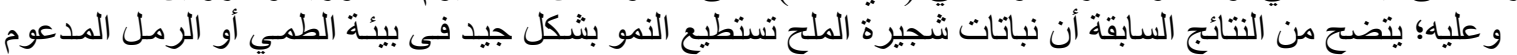

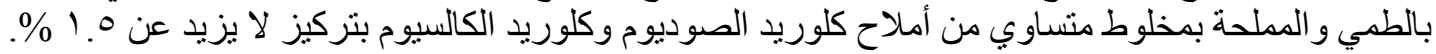

